\title{
STUDIES ON HYPERSENSITIVITY TO PENICILLIN. I. INCIDENCE OF REACTIONS IN 1303 PATIENTS ${ }^{1,2}$
}

\author{
BY MARK H. LEPPER, HARRY F. DOWLING, JAY A. ROBINSON, THOMAS E. \\ STONE, ROBERT L. BRICKHOUSE, ESTON R. CALDWELL, JR., \\ AND RICHARD L. WHELTON
}

(From the George Washington University Medical Division, Gallinger Municipal Hospital, and the Department of Medicine, George Washington University, Washington, D. C.)

Although penicillin is a relatively safe drug, many reactions, including three deaths (1-3), have been reported following its administration. Most of these reactions appear to be allergic in origin, even though the nature of the antigen has usually not been determined. During the years that penicillin was being purified many reactions were considered to be caused by impurities, particularly when the reaction was specific for a particular lot. When slowly absorbable preparations became available it seemed important to determine whether administration in this form increased the incidence of reactions. We have undertaken a study to determine the reaction rate to crystalline penicillin in aqueous solutions and to slowly absorbable forms as seen in ordinary hospital practice as well as factors influencing the incidence of such reactions and the nature of the antigen involved. In the present paper we are reporting the incidence of reactions which we have found and some of the factors believed to be important in determining the reaction rate. Studies on skin tests with penicillin oil and beeswax will be reported elsewhere (4).

\section{METHOD}

The method of this study was to observe daily all patients being treated with a preparation containing penicillin. Before treatment was initiated the patients were questioned regarding previous courses of penicillin and previous allergic reactions. A physical examination was then performed and the type of preparation, the dose, and the lot number of the penicillin employed were recorded. At least once a day each patient was examined and questioned closely regarding signs and symptoms of allergic reactions and of reactions at the site of injection. At

1 Presented at the Second National Symposium on Recent Advances in Antibiotics Research held in Washington, D. C., April 11-12, 1949, under the auspices of the Antibiotics Study Section, National Institutes of Health, Public Health Service, Federal Security Agency.

2 Aided by a Grant from the Antibiotics Study Section, National Institutes of Health. the start of the study it was anticipated that most of the patients would be given a second course of penicillin after an interval of several days in order to bring out latent sensitivities. It soon became apparent that this procedure produced very few allergic reactions so that the method was abandoned. As a result, in order to demonstrate statistically significant differences between the various preparations of penicillin we were forced to rely mainly on the observation of a large number of patients receiving each preparation.

The diagnosis of allergic reactions, where no confirmatory data were available ( such as a positive reaction to a skin test or to a second course), was made on clinical grounds by the appearance of the reaction when penicillin was being administered and its disappearance shortly after the antibiotic was discontinued and by the fact that no other allergen could be indicted. Patients who developed reactions typical of serum sickness shortly after penicillin administration were considered penicillin reactors if no other reasons were found for such a reaction.

\section{RESULTS}

A total of 1303 patients who were under treatment for various infections were followed in this manner. As shown in Table I, 598 received aqueous crystalline penicillin, 557 were given crystalline penicillin in oil and beeswax, and 148 received procaine penicillin in oil. The incidence of allergic reactions in these groups was 1.2, 2.7, and 1.4 per cent respectively. The rates were significantly higher for the oil and wax group than for the aqueous group. There were not enough patients who received procaine penicillin to make the difference between this and the other groups statistically significant. An analysis of the effect of the size of the dose used on the incidence of reactions revealed that in the oil and beeswax and in the procaine penicillin groups, where maximum dose employed was only four times the minimum dose, no difference in the reaction rate with moderate and low doses was found. In the aqueous penicillin group, however, many of the doses used were ten or more times the usual doses employed. Thus, if the patients receiving 500,000 
TABLE I

Incidence of allergic reactions following administration of various penicillin preparations

\begin{tabular}{|c|c|c|c|c|c|c|c|c|c|}
\hline \multirow{3}{*}{ Preparation } & \multirow{3}{*}{ Dose } & \multicolumn{6}{|c|}{ Duration } & \multirow{2}{*}{\multicolumn{2}{|c|}{ All cases }} \\
\hline & & \multicolumn{2}{|c|}{ 0-5 days } & \multicolumn{2}{|c|}{$6-10$ days } & \multicolumn{2}{|c|}{ Over 10 days } & & \\
\hline & & $\begin{array}{l}\text { No. of } \\
\text { patients }\end{array}$ & $\begin{array}{l}\text { No. re- } \\
\text { actions }\end{array}$ & $\begin{array}{l}\text { No. of } \\
\text { patients }\end{array}$ & $\begin{array}{l}\text { No. re- } \\
\text { actions }\end{array}$ & $\begin{array}{l}\text { No. of } \\
\text { patients }\end{array}$ & $\begin{array}{l}\text { No. re- } \\
\text { actions }\end{array}$ & $\begin{array}{l}\text { No. of } \\
\text { patients }\end{array}$ & $\begin{array}{l}\text { No. re- } \\
\text { actions }\end{array}$ \\
\hline \multirow{2}{*}{$\begin{array}{l}\text { Crystalline penicillin in } \\
\text { oil and beeswax }\end{array}$} & Low, $300,000 \mathrm{U}$ daily & 153 & 3 & 77 & 4 & 40 & 2 & 270 & $9(1)$ \\
\hline & $\begin{array}{l}\text { Moderate, over } 300,000 \\
\text { U daily thru } 600,000 \mathrm{U} \\
\text { B.I.D. }\end{array}$ & 145 & 3 & 94 & 1 & 48 & 2 & 287 & $6(2)$ \\
\hline \multirow[t]{3}{*}{$\begin{array}{l}\text { Crystalline penicillin in } \\
\text { aqueous solution }\end{array}$} & $\begin{array}{l}\text { Low, } 50,000 \mathrm{U} \text { q3h or } \\
\text { less }\end{array}$ & 176 & 0 & 184 & 2 & 123 & 1 & 483 & $3(3)$ \\
\hline & $\begin{array}{l}\text { Moderate, over } 50,000 \mathrm{U} \\
\text { q3h to } 500,000 \mathrm{U} \text { q2h }\end{array}$ & 21 & 0 & 24 & 0 & 19 & 0 & 64 & $0(4)$ \\
\hline & High, over $500,000 \mathrm{U}$ q2h & 27 & 0 & 6 & 2 & 18 & 2 & 51 & $4(5)$ \\
\hline \multirow{2}{*}{$\begin{array}{l}\text { Procaine penicillin } \\
\text { in oil }\end{array}$} & Low, $300,000 \mathrm{U}$ daily & 59 & 2 & 9 & 0 & 9 & 0 & 77 & 2 \\
\hline & $\begin{array}{l}\text { Moderate, over } 300,000 \\
\text { U daily to } 600,000 \mathrm{U} \\
\text { B.I.D. }\end{array}$ & 39 & 0 & 22 & 0 & 10 & 0 & 71 & 0 \\
\hline Total & & 620 & 8 & 416 & 9 & 267 & 7 & 1303 & 24 \\
\hline
\end{tabular}

All of the following are significant by the Chi Square Test. $1+2>3+4+5$

units or more every two hours are compared to those receiving less than this amount, reaction occurred in four among 51 patients (7.8 per cent) and in three among 547 patients ( 0.6 per cent) respectively. This difference is statistically sig-

TABLE II

Comparison of incidence of allergic reactions to crystalline penicillin and sulfamerazine at different doses

\begin{tabular}{|c|c|c|c|c|}
\hline Preparation & Dose & Patients & \multicolumn{2}{|c|}{ Reactions } \\
\hline $\begin{array}{l}\text { Crystalline } \\
\text { penicillin }\end{array}$ & $\begin{array}{r}\text { Less than } 500,000 \\
U \text { every } 2 \text { hours }\end{array}$ & 547 & $\begin{array}{c}\text { Patients } \\
3\end{array}$ & $\begin{array}{l}\% \\
0.6\end{array}$ \\
\hline Do & $\begin{array}{l}500,000 \mathrm{U} \text {. or more } \\
\text { every } 2 \text { hours }\end{array}$ & 51 & 4 & 7.8 \\
\hline Sulfamerazine & $\begin{array}{l}\text { Initial dose } 6 \text { gm., } \\
\text { then } 1 \text { gm. every } \\
4 \text { hours }\end{array}$ & 35 & 2 & 5.9 \\
\hline Do & $\begin{array}{l}\text { Initial dose } 2 \mathrm{mg} \text {., } \\
\text { then } 0.5 \mathrm{gm} . \\
\text { every } 4 \text { hours }\end{array}$ & 87 & 3 & 3.4 \\
\hline Do & $\begin{array}{l}\text { Initial dose } 1 \mathrm{gm} ., \\
\text { then } 0.5 \mathrm{gm} . \\
\text { every } 8 \text { hours }\end{array}$ & 58 & 1 & 1.7 \\
\hline
\end{tabular}

nificant when tested by the chi square test. Table II compares these rates with similar figures obtained by us for one of the sulfonamides (sulfamerazine). There is a trend in our figures which indicates that the incidence of reactions increased as the duration of therapy was prolonged although there are too few reactions to be certain of this point.

Two factors found to be of significance in the

TABLE III

Relationship of history of previous allergy to reactions to penicillin

\begin{tabular}{l|c|c}
\hline \hline \multicolumn{1}{c|}{ Group } & $\begin{array}{c}\text { History of } \\
\text { allergy }\end{array}$ & $\begin{array}{c}\text { No. history of } \\
\text { allergy }\end{array}$ \\
\cline { 1 - 2 } $\begin{array}{c}\text { Non-reactors in controlled } \\
\text { group }\end{array}$ & 177 & 848 \\
$\begin{array}{l}\text { Reactors to penicillin in con- } \\
\text { trolled group }\end{array}$ & $7 *$ & $13^{*}$ \\
$\begin{array}{l}\text { Reactors in controlled group } \\
\text { believed to be allergic to } \\
\text { vehicle used }\end{array}$ & 1 & 3 \\
$\begin{array}{c}\text { All reactors to penicillin } \\
\text { All reactors believed to be } \\
\text { allergic to vehicle used }\end{array}$ & 1 & 22 \\
\hline
\end{tabular}

* $7 / 184$ is significantly greater than $13 / 861$ by $\mathrm{Chi}^{2}$ 'Test. 
TABLE IV

Relationship of previous penicillin administration to reactions to penicillin

\begin{tabular}{l|c|c}
\hline \multicolumn{1}{c|}{ Group } & \multicolumn{2}{|c}{$\begin{array}{c}\text { History of receiving } \\
\text { previous penicillin }\end{array}$} \\
\cline { 2 - 3 } & Yes & No \\
\hline $\begin{array}{l}\text { Non-reactors in controlled } \\
\text { group }\end{array}$ & 21 & 376 \\
$\begin{array}{l}\text { Reactors to penicillin in con- } \\
\text { trolled group }\end{array}$ & $8^{*}$ & $12^{*}$ \\
$\begin{array}{l}\text { Reactors in controlled group } \\
\text { believed to be allergic to } \\
\text { vehicle used }\end{array}$ & 2 & 2 \\
$\begin{array}{l}\text { All reactors to penicillin } \\
\text { All reactors believed to be } \\
\text { allergic to vehicle used }\end{array}$ & 18 & 22 \\
\hline
\end{tabular}

* $8 / 29$ is significantly greater than $12 / 388$ by $\mathrm{Chi}^{2}$ Test.

incidence of reactions to penicillin are a previous allergic history and the previous administration of penicillin. Tables III and IV illustrate these data. Reactions believed to be caused by penicillin itself and by the vehicles used (as determined by second courses and/or skin tests) are listed separately. The patients in this, the controlled series, who showed reactions to penicillin are listed alone and are also included in the total group of reactors to penicillin. This total includes, in addition, the penicillin reactors whom we observed from all other available sources. In the controlled group there is a significantly greater reaction rate among individuals with such a history, and such a history was obtained in 35 per cent of the penicillin reactors. Since some of the patients outside of the controlled series who were available to us for study following a penicillin reaction were obtained from a private practice in allergy, the overall group is weighted in favor of persons with a history of some previous manifestation of allergy.

The high incidence of reactors who had received previous penicillin is of interest (Table IV). In both the controlled series and the total group there was a large percentage of patients who had

TABLE V

Local reactions to various penicillin preparations

\begin{tabular}{|c|c|c|c|c|c|c|c|c|c|c|c|c|c|c|c|c|c|}
\hline \multirow{3}{*}{ Preparation } & \multirow{3}{*}{ Dose } & \multicolumn{12}{|c|}{ Duration of treatment } & \multicolumn{4}{|c|}{ All cases } \\
\hline & & \multicolumn{4}{|c|}{ 0-5 days } & \multicolumn{4}{|c|}{$6-10$ days } & \multicolumn{4}{|c|}{ Over 10 days } & \multirow{2}{*}{$-\begin{array}{c}\text { No. of } \\
\text { patients }\end{array}$} & \multicolumn{3}{|c|}{ Reactions } \\
\hline & & $\begin{array}{l}\text { No. of } \\
\text { patients }\end{array}$ & Mild & Mod. & $\begin{array}{l}\text { Se- } \\
\text { vere }\end{array}$ & $\begin{array}{l}\text { No. of } \\
\text { patients }\end{array}$ & Mild & Mod. & $\begin{array}{c}\text { Se- } \\
\text { vere }\end{array}$ & $\begin{array}{l}\text { No. of } \\
\text { patients }\end{array}$ & Mild & Mod. & \begin{tabular}{|l|} 
Se- \\
vere
\end{tabular} & & Mild & Mod. & Sev. \\
\hline \multirow{2}{*}{$\begin{array}{l}\text { Crystalline } \\
\text { penicillin in } \\
\text { oil and bees- } \\
\text { wax }\end{array}$} & $\begin{array}{l}\text { Low, 300,000 U } \\
\text { daily }\end{array}$ & 118 & 11 & 4 & 2 & 51 & 8 & 5 & 2 & 16 & 5 & 3 & 3 & 185 & 24 & 12 & 7 \\
\hline & $\begin{array}{l}\text { Moderate, over } \\
300,000 \text { U daily } \\
\text { thru } 600,000 \text { U } \\
\text { B.I.D. }\end{array}$ & 85 & 25 & 6 & 3 & 28 & 10 & 6 & 2 & 19 & 11 & 4 & 4 & 132 & 46 & 16 & 9 \\
\hline \multirow{3}{*}{$\begin{array}{l}\text { Crystalline } \\
\text { penicillin in } \\
\text { aqueous } \\
\text { solution }\end{array}$} & $\begin{array}{l}\text { Low, } 50,000 \mathrm{U} \\
\text { q3h or less }\end{array}$ & 141 & 10 & 1 & 0 & 140 & 7 & 0 & 0 & 116 & 13 & 2 & 1 & 397 & 30 & 3 & 1 \\
\hline & $\begin{array}{l}\text { Moderate, more } \\
\text { than } 50,000 \mathrm{U} \\
\text { q3h to } 50,000 \mathrm{U} \\
\mathrm{q} 2 \mathrm{~h}\end{array}$ & 16 & 0 & 1 & 0 & 12 & 2 & 0 & 0 & 2 & 0 & 0 & 0 & 30 & 2 & 1 & 0 \\
\hline & $\begin{array}{l}\text { High, } 500,000 \mathrm{U} \\
\text { q2h and over }\end{array}$ & 17 & 6 & 3 & 0 & 3 & 1 & 1 & 0 & 10 & 4 & 0 & 1 & 30 & 11 & 4 & 1 \\
\hline \multirow{2}{*}{$\begin{array}{l}\text { Procaine } \\
\text { penicillin in } \\
\text { oil }\end{array}$} & $\begin{array}{l}\text { Low, } 300,000 \mathrm{U} \\
\text { daily }\end{array}$ & 28 & 4 & 0 & 0 & 9 & 1 & 0 & 0 & 9 & 0 & 0 & 0 & 46 & 5 & 0 & 0 \\
\hline & $\begin{array}{l}\text { Moderate, more } \\
\text { than } 300,000 \mathrm{U} \\
\text { daily thru } \\
600,000 \mathrm{U}- \\
\text { B.I.D. }\end{array}$ & 36 & 8 & 0 & 0 & 20 & 3 & 0 & 0 & 10 & 1 & 0 & 0 & 66 & 12 & 0 & 0 \\
\hline Total & & 441 & 64 & 15 & 5 & 263 & 32 & 12 & 4 & 182 & 34 & 9 & 9 & 886 & 130 & 36 & 18 \\
\hline
\end{tabular}


previously received penicillin (40 and 45 per cent, respectively). In the controlled group the reaction rate among patients who had previously received penicillin was significantly higher than the rate among those to whom the penicillin was given for the first time ( 28 per cent versus 3 per cent).

Reactions in the controlled group were somewhat more frequent in males (12 reactions among 683 males) than in females (eight out of 600 ). The incidence of reactions in the white patients (eight in 389 patients) was greater than that for the Negroes (12 in 894 patients), but this is not statistically significant.

We had little success in demonstrating latent allergy by giving second courses routinely. Among 122 patients who received second courses of aqueous crystalline penicillin only one had a reaction, while 111 patients received a second course of crystalline penicillin in wax and oil and 28 a second course of procaine penicillin without exhibiting a reaction. Almost all of the intervals allowed between the first and second courses were under ten days, and the majority were three, four, or five days. The one reaction occurred on the third day of the second course, ten days following the first course.

Eight hundred and eighty-six patients were studied by daily observation for the occurrence of local irritative reactions, which were graded as mild, moderate and severe depending upon the degree of pain, tenderness, induration, edema, and redness present. It was found (Table $\mathrm{V}$ ) that pencillin in oil and wax caused significantly more irritative reactions than aqueous crystalline penicillin (36 per cent compared with 12 per cent). Procaine penicillin in oil although it caused more mild local reactions than aqueous penicillin produced no moderate or severe reactions at all, and therefore in the doses used appeared to be the least irritating of the three preparations. In the case of penicillin in oil and wax and aqueous penicillin, the dose and duration of treatment appeared to be directly related to the incidence and severity of the local reactions.

\section{DISCUSSION}

The incidence of penicillin reactions has been reduced by the use of crystalline penicillin. Keefer and his colleagues (5) using crude penicil- lin reported 69 reactions among 500 patients although it is uncertain how many of these were allergic in nature. Lyons (6) reported urticaria in 5.7 per cent of 209 patients receiving crude penicillin. Duemling (7) reported a 10 per cent reaction rate including Herxheimer reactions in 17,879 patients treated for 65 different conditions. The patients were treated over the years during which penicillin was being purified and thus penicillin of varying degrees of purity was used in these patients. Thomas and co-workers (8) reported 2.5 per cent of 10,000 syphilitics developed urticaria following therapy. Peck and co-workers (9) observed 32 reactions among 130 patients who received crystalline penicillin. The overall incidence of reactions in our series of 1.2 per cent for aqueous crystalline penicillin patients, 2.7 per cent for crystalline penicillin in oil and beeswax and 1.4 per cent for procaine penicillin in oil are compatible with most of these figures. Since some of our patients were discharged a few days after penicillin was discontinued and since we know that certain delayed penicillin reactions may occur after a longer interval than this even when the aqueous preparation is used; the reported rates may be somewhat low.

It is of interest that there are significantly more reactions when the penicillin is administered in oil and beeswax. Even though three of these reactions may have been caused by the vehicle (10), this does not account for all of the difference. The dose used is evidently not the key to the situation since the penicillin in oil and wax doses did not exceed the moderate range and when the reactions in this group are compared with those occurring in the aqueous penicillin patients who received comparable doses, the greater tendency of the oil and wax preparations to cause reactions is even more pronounced. Moreover, moderate doses of penicillin in oil and wax gave no higher reaction rates than the low doses $(300,000$ units per day). Two factors which may be of importance are that the penicillin is held in contact with the tissues in one site over a prolonged period of time, and in the same area as evidenced by the local irritation there are probably many damaged proteins which may conjugate with the penicillin and render it antigenic. Observation of a larger group of patients under treatment with procaine penicillin may indicate whether the prolonged 
contact or the irritative component is more important. That more reactions of the delayed type occur after the use of penicillin in oil and wax than after the use of aqueous penicillin may indicate that the prolonged contact locally or systemically is important. Some of these reactions, however, are probably caused by a metabolic product of penicillin particularly since they do follow the use of aqueous penicillin. Inasmuch as the skin is an important organ for causing penicillin sensitization it is possible that the minute quantities of penicillin in oil and wax escaping into the cutaneous tissue are important. Small amounts of wax and oil will remain in the skin for a prolonged period when injected intracutaneously (4) and may hold penicillin there in contact with the tissue for some time.

The fact that the employment of very high doses of aqueous penicillin results in a high reaction rate may depend on the fact that these large amounts produce considerable local irritation, even though for only a relatively brief period, with the result that more proteins are available to conjugate with the large amount of penicillin present at the site. On the other hand the concentration of penicillin or a metabolic product of it in the distant organs may be more important. In this connection the fact that when high doses of penicillin are given the reaction rate approximates that obtained with a sulfonamide indicates that penicillin is rather allergenic in large doses and that the difference between it and the sulfonamides may be mainly a question of dosage.

Our data indicate that an underlying allergic diathesis may be important in the development of penicillin allergy. We have examined the histories of 138 patients reported in the literature. Among the cases in which a history of allergy is mentioned, the history was positive in 18 per cent.

Among the 138 histories examined, 63 patients had previously received penicillin therapy, locally or systemically, at least once and 16 patients had received none. No data on previous penicillin administration were recorded for the 59 remaining patients. If the latter patients are omitted from the calculation, about 80 per cent of the reactors had previous contact with penicillin. Our figures are in agreement with a high incidence of previous exposure.
In this connection our failure to demonstrate "latent" allergy by administering a second course of penicillin is of interest. It is possible that the interval allowed in many of the patients was too short, since we have observed delayed reactions after the discontinuance of penicillin with incubation periods longer than the time which we allowed between courses in most patients. Furthermore, the intervals in the patients who reacted to penicillin treatment were much longer both in our cases and in those reported, usually a matter of months rather than a few days.

Peck and co-workers (9) have reported that the incidence of reactions is much higher among males than among females. Although the rate was somewhat higher among our male patients than among our female patients, the difference was not statistically significant. The reaction rate in Negroes may be lower than that for white patients. This problem deserves further study.

The fact that the incidence of allergic reactions and local irritative reactions seem to parallel one another may indicate a cause and effect relationship as discussed above. This is not necessarily so, however, since several mechanisms are available to explain the production of each phenomenon. Certainly some patients with severe local reactions do not have allergic reactions whereas others with no demonstrable local reaction may have severe allergies so that even if the two phenomena are related other determinants may be operative.

\section{SUM MARY}

1. The incidence of allergic reactions was studied in 1303 patients. Among 598 patients receiving aqueous crystalline penicillin the rate was 1.2 per cent, among 557 patients receiving crystalline penicillin in oil and beeswax it was 2.7 per cent, and among 148 patients receiving procaine penicillin in oil it was 1.4 per cent. In patients receiving very large doses of the aqueous preparation the reaction rate was high ( 7.8 per cent). Reactions were more frequent when a product was administered for a longer period of time.

2. Reactions were more frequent among patients who gave a history of previous allergy or who had previous known contact with penicillin. The effect of sex and race on the incidence of reactions was not significant in this group of patients. 
3. Local irritative reactions were more frequent and more severe with penicillin in oil and beeswax than with aqueous crystalline penicillin and procaine penicillin in oil. Higher doses and/ or more prolonged therapy were likely to be accompanied by a higher incidence of irritative reactions.

\section{BIBLIOGRAPHY}

1. Wilensky, A. O., Fatal delayed anaphylactic shock after penicillin. J. A. M. A., 1946, 131, 1384.

2. Waldbott, G. L., Anaphylactic death from penicillin. Ibid., 1949, 139, 526.

3. Rabinovitch, J., and Snitkoff, M. C., Acute exfoliative dermatitis and death following penicillin therapy. Ibid., 1948, 138, 496.
4. Lepper, M. H., Brown, H., and Dowling, H. F., Data to be published.

5. Keefer, C. S., Blake, F. G., Marshall, E. K., Jr., Lockwood, J. S., and Wood, W. B., Jr., Penicillin in the treatment of infections ( 500 cases). J. A. M. A., 1943, 122, 1217.

6. Lyons, C., Penicillin therapy of surgical infections in the U. S. army. Ibid., 1943, 123, 1007.

7. Duemling, W. W., Clinical experience with penicillin in the navy. Ann. N. Y. Acad. Sci., 1946, 48, 201.

8. Thomas, E. W., Landy, S., and Cooper, C., Reactions to penicillin therapy for syphilis. J. Invest. Dermatol., 1948, 10, 77.

9. Peck, S. M., Sheppard, S., Glick, A. W., and Kurtin, A., Clinical problems in penicillin sensitivity. J. A. M. A., 1948, 138, 631.

10. Lepper, M. H., and Dowling, H. F., Unpublished data. 